RESEARCHS / INVESTIGACIÓN

\title{
Evaluation of Rapeseed (Brassica napus L.) maturity and productivity for accumulative temperature
}

\author{
Ziadoon M. Jaafar ${ }^{1}$, Mahmood A. Ramadhan ${ }^{1}$, Raghad S. Mouhamad ${ }^{1 *}$, Rasha A Mussa², Buthaina A. Jassim², Ahmed J. Husain² .
}

DOI. 10.21931/RB/2019.04.01.7

\begin{abstract}
Field experiment conducted during the winter agricultural season 2017-2018 at Al-Zafraniya Agricultural Research Station and Al-Tuwaitha Agricultural Research Station, according of Randomized Complete Block Design (RCBD) with three replications, to study maturity and productivity for accumulative temperature of rapeseed (Brassica napus L.). The experiment planting in Last week of September 2017 at Al-Zafraniya station and Last week of October 2017 at AL- Tuwaitha station. The results show increasing significantly in the yield (1110.11 kg. ha-1), percentage of oil (47.12\%), protein content in seeds (43.1\%), carbohydrate (25.7\%), nutrient content of seed (K, Ca) in Al-Zafraniya location; compared to Al-Tuwaitha location, yield (352.8 $\mathrm{kg}$. ha $\mathrm{a}^{-1}$ ), percentage of oil (41.1\%), protein content in seeds (41.2\%), carbohydrate (26.2\%), nutrient content of seed ( $\mathrm{Na}$, Ca, $\mathrm{Mg}, \mathrm{Fe}$ ) at fertilization, compared to no-fertilizer. It showed significant differences with nutrient content of soil ( $\mathrm{Na}, \mathrm{Mg}, \mathrm{Fe})$ for Al-Tuwaitha location and nutrient content of soil ( $\mathrm{K}, \mathrm{Ca}, \mathrm{Mg}, \mathrm{Fe}, \mathrm{S}, \mathrm{Cu}$ ), pH, EC for Al-Zafraniya location at fertilization, compared to no-fertilizer. These results shows that the delay at time of cultivation leads to a decrease in seed yield, oil ratio, and percentage of protein in seeds, also high temperatures at seed filling stage leads decrease in seeds, oil and protein content.
\end{abstract}

Keywords: Productivity, Seed yield, Oil content, Rapeseed (Brassica napus L.)

\section{Introduction}

Brassica genus is native in the wild in Western Europe, the Mediterranean and temperate regions of Asia. In addition to the cultivated species, which grown worldwide, many of the wild species grow as weeds, especially in North America, South America, and Australia ${ }^{1}$ (Cohen et al., 2000). Brassica napus L. can be cultivated under different environmental conditions; there are winter varieties grown early and late. The rapeseed effected by frost, which negatively affects the composition of flowers and pollen, the maturity of seeds and the proportion of oil in seeds. Rapeseed plants need a light period between 10-24 hours. Shading and low temperatures lead to fewer flowers, pods and seeds ${ }^{2}$ (Taifour et al., 1990). Robertson et al., $1999{ }^{3}$ found that the delay in the date of cultivation leads to fluctuation in seed yield between -10 to $+4 \%$ per week delay. It is important genus in the Brassicaceae family, several species and types of Brassicas. In Iraq has a suitable climate for many oilseeds crops. This is not completely true in North with low temperatures and short growing season, where the oilseed crops usually perform poorly except sunflower and rapeseed.

Rapeseed (Brassica napus L.) is a new and promising oilseed crop for this region, its seed high oil content ranging from 45-60 percent and is rich in protein (34-40) percent ${ }^{4}$ (Shirani and Ahmedi 1995). It mainly used in the meat packing industry as an aid to flavor, emulsification, water binding, slicing, bologna and other processed meats. Ground Rapeseed can absorb excess fat and fluid (approximately 4.5 times its own weight) and also used with seasoned hamburger, meatloaf, liver sausage, chili, various canned meat products. Under iraqi conditions, Al-Mandil and Kanah $(2017)^{5}$ reported that Brassica napus that were collected from four sites of the city of Mosul, Al-Rashidiya, Shalalat AlMosul, Mosul University, while the fourth site at the village of Abukudoor in spite of the soils were varying in the values of the elements that have been insignificant in Phenolic compounds (Hydroquinone, Resorcinol, Gallic acid, Vanillin and Salicylic acid), Expect Gallic acid was absence from all of these extracts with the exception of sample that collected from Shalalat Al-Mosul. Which characterized with highest value for phosphorus compared to other sites. Also, in Al-Mosul that AL-Doori and Hasan $(2010)^{6}$ investigated the effects of different row spacing $(30-60 \mathrm{~cm})$ in rapeseed, they concluded that number of siliques per plant, seed weights and dry matter per plant, weight of thousand seed and oil yield increases as row spacing increased.

In AL-Sulaimani, Abdulkhaleq et al. (2018) ${ }^{7}$ she expertise at The Qlyasan Agricultural Research Station, College of Agricultural Sciences, University of Sulaimani, using three levels of zinc fertilizer on seed yield showed positive and highly significant correlation on seed yield recorded by an average pod weigh with 0.898 , while the maximum positive indirect effect on seed yield recorded by biological yield via average pod weight with 0.840 .

Previous study (Hassan and El-Hakeem, 1996) revealed that nitrogen reduced oil percentage of the seed. Nitrogen increases seed and oil yields by influencing a number of growth parameters such as seeds per silique and seed weight and by producing more vigorous growth and development ${ }^{8}$ (Sharief, 2000). Winter oilseed rape can be used as a catch crop to reduce nitrogen leaching during the autumn-winter period because of its high capacity to take up nitrate from the soil. Other work on oilseed rape grown hydroponically or in field conditions showed that $\mathrm{NO}_{3}$ uptake increased from stem extension to the start of the flowering, whereas little $\mathrm{NO}_{3}$ uptake was observed during Silique filling ${ }^{9}$ (Rossato et al, 2001). Yield response of Rapeseed to increasing Nitrogen rate with different environmental variables, including weather, soil type, residual fertili- 
ty (especially nitrate), soil moisture, and cultivars ${ }^{10}$ (Hocking, 1997).

\section{Materials and methods}

This study carried out in Iraq at the Al-Zafraniya Agricultural Research Station (Latitude $33^{\circ} 13$ 20.8"; N, Longitude $44^{\circ}$ 30 16.0" E, 765 MASL), located 2 km south of Baghdad city and the Al-Tuwaitha Agricultural Research Station (Latitude

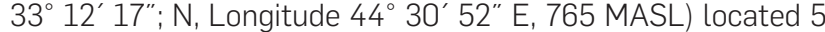
$\mathrm{km}$ south west of Baghdad city during the winter seasons of 2017-2018. The meteorological data of two stations location is shown in Table 1.

The experimental area plots were ploughed twice, harrowed and well leveled. A brief account of some physical and chemical properties of the experimental soil is given in Table (2). The experiment was carried out in (Last week of September 2017 at Al-Zafraniya station, Last week of October 2017 at AL- Tuwaitha station) according of Randomized Complete Block Design (RCBD) with three replications. Rapeseed were planting in row with spacing $30 \mathrm{~cm}$ in plot $(1 \times 2) \mathrm{m}^{2}$; the plots were separated by $0.5 \mathrm{~m}$ in width from all sides to avoid the effect of fertilization and Field fertilizer (N $100 \mathrm{~kg}^{\text {. ha-1 }}$, P 250 $\mathrm{kg}$. ha-1) added. The nutrient parameters measured during period study, and nutritive value in terms of minerals of $\mathrm{K}, \mathrm{Ca}, \mathrm{Mg}$, $\mathrm{Na}, \mathrm{Zn}, \mathrm{Mn}, \mathrm{Cu}$, and Fe. One gram of tissues and soil form each replicate were dried in an oven for $24 \mathrm{~h}$ at $105^{\circ} \mathrm{C}$ (weighed and re-weighed until a constant weight was reached). The samples were allowed to cool at room temperature before the final weight was taken. The contents of the mineral elements for $\mathrm{K}, \mathrm{Ca}$, $\mathrm{Na}, \mathrm{Mg}, \mathrm{Mn}, \mathrm{Zn}, \mathrm{Cu}$ and Fe were determined using the standard method (aqua regain digestion method) and analyzed by Atomic Absorption Spectroscopy (AAS), method of described by Page ${ }^{16}$
The chemical composition of triplicate plant samples was grounded and analyzed for moisture content, carbohydrate, ash, protein (the total protein content was determined by the Kjeldahl method (a nitrogen conversion factor of 5.95), and oil as per the methods of the Association of official Analytical chemists AOAC ${ }^{5}$. Data were analyzed using the SAS 1999 software and means were separated using the stander error ${ }^{21}$

Statistical Analysis: The LSD test was done to find the significant differences between treatment means at $5 \%$ probability level. Mature plants were harvested on July 20, of 2017 for estimating seed yield, yield components and growth rate.

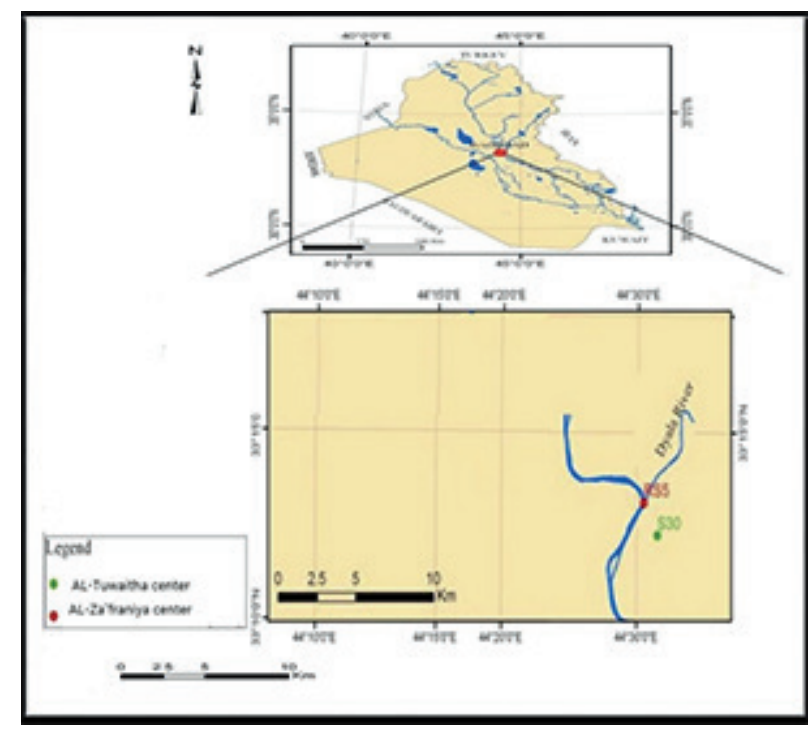

Fig 1. Map showing the location of the studied area

\begin{tabular}{|c|c|c|c|c|c|c|}
\hline \multirow[t]{3}{*}{ Month } & \multicolumn{6}{|c|}{ Field fertilizer } \\
\hline & \multicolumn{3}{|c|}{ Al-Zafraniyastation } & \multicolumn{3}{|c|}{ Al-Tuwaithastation } \\
\hline & $\begin{array}{l}\text { Monthly absolute } \\
\text { minimum } \\
\text { temperature C }\end{array}$ & $\begin{array}{l}\text { Monthly absolute } \\
\text { maximum } \\
\text { temperature C }\end{array}$ & $\begin{array}{l}\text { Aver.te } \\
\text { mp. C }\end{array}$ & $\begin{array}{c}\text { Monthly absolute } \\
\text { minimum } \\
\text { temperature C }\end{array}$ & $\begin{array}{l}\text { Monthly absolute } \\
\text { maximum } \\
\text { temperature C }\end{array}$ & Aver. temp. C \\
\hline Sep.2017 & 19.3 & 39 & 29.21 & 19.5 & 40 & 30 \\
\hline Oct. & 06.2 & 19.3 & 12.74 & 06.8 & 18.9 & 13 \\
\hline Nov. & 06.8 & 18.7 & 12.78 & 06.8 & 18.9 & 13 \\
\hline Dec. & 01.2 & 13.41 & 07.39 & 01.4 & 14.1 & 07.9 \\
\hline Jan.2018 & 01.35 & 10.56 & 06.1 & 01.7 & 11 & 06.4 \\
\hline Feb. & 04.44 & 16.87 & 10.55 & 04.9 & 17.1 & 11.1 \\
\hline Mar. & 06.54 & 18.10 & 12.60 & 06.8 & 19.1 & 13.01 \\
\hline Apr. & 11.0 & 25.67 & 12.58 & 11.2 & 26.1 & 13.2 \\
\hline May & 14.89 & 30.12 & 23.2 & 15.02 & 31.02 & 20.1 \\
\hline
\end{tabular}

Table 1. Growing season (29/9/2017-29/5/2018) weather summary for Al-Zafraniya station and Al-Tuwaitha station (29/10/2017-29/6/2018) location study.

\begin{tabular}{|c|c|c|c|c|c|c|c|c|}
\hline \multirow[t]{2}{*}{ Location } & \multirow[t]{2}{*}{ Coordinate } & \multicolumn{3}{|c|}{ Grain size analysis \% } & \multirow[t]{2}{*}{ Type of soil } & \multirow{2}{*}{$\begin{array}{c}\text { CEC } \\
\text { meq/100gm }\end{array}$} & \multirow[t]{2}{*}{ O.M\% } & \multirow[t]{2}{*}{$\mathrm{Fe}_{2} \mathrm{O}_{3} \%$} \\
\hline & & Sand & Silt & Clay & & & & \\
\hline Al-Zaifraniya & $\begin{array}{l}\mathrm{N} 33^{\circ} 13 \cdot 20.8^{\prime \prime} \\
\mathrm{E} 44^{\circ} 30^{\prime} 16.0^{\prime \prime}\end{array}$ & 19.73 & 56.14 & 24.13 & sandy silt & 12.5 & 1.31 & 5.4 \\
\hline AI-Tuwaitha & $\begin{array}{l}\mathrm{N} 33^{\circ} 12^{\circ} 17^{\prime \prime} \\
\mathrm{E} 44^{\circ} 30^{\circ} 52^{\prime \prime}\end{array}$ & 2.53 & 54.27 & 43.20 & Mud & 17.2 & 1.27 & 4.8 \\
\hline
\end{tabular}

Table 2. Physico-chemical properties of area under study 


\section{Results and discussion}

Results of Table 3 were shows increasing significantly in the seed yield $\left(898.5^{\mathrm{b}}-1110.11^{\mathrm{c}} \mathrm{kg}\right.$. ha-1) in Al-Zafraniya station at fertilization, compared to no-fertilization. Al-Tuwaitha station found decrease significant differences in the seed yield (366. $2^{\mathrm{a}}$ - 352.8 $\mathrm{kg}$. ha-1 $)$ at fertilization, compared to no-fertilization (Fig 2). The status of seed yield is the most important field scale, giving the final evaluation of agricultural operations to produce new recommendations on production. Through the results, we show increasing the seed yield when sowing date (29-Sept-2017) compared to the second date (29-Oct-2017). The high seed yield on the first date may be due to climatic conditions and increase the number of capsules in the plant and the number of seeds in capsules. (Rahman et al., 2000) ${ }^{14}$ showed agriculture in September was better than agriculture in October for a high yield of seeds and oil. The delay in sowing date of rapeseeds leads to slow vegetative growth of the plant and low speed of photosynthesis due to low paper area of the plant and an increase in the fall of flowers and capsules (abortion), (Mendham., 1981)15. The decrease in the second date (29/10/2017) was due to high temperature $\left(19.1^{\circ} \mathrm{C}\right)$ during the flowering period (Mar. month) (Table 1). Anne et al. (1999) ${ }^{16}$ found the high temperature from $18-26{ }^{\circ} \mathrm{C}$ during the flowering period of rapeseeds leads to decrease in the seed yield.

Chemical components, including percentage of oil, protein content in seeds, carbohydrate, are important traits to be considered in the study of rapes (Brassica napus L.). The results shows increasing significantly in the percentage of oil (47.12 $\%)$, protein content in seeds (42.1\%), carbohydrate (25.7\%) in Al-Zafraniya station at fertilization (Table 3, Fig 3). As well as in Al-Tuwaitha station found decrease significant differences in percentage of oil (41.1\%), protein content in seeds (41.2\%), carbohydrate (26.2 \%) at fertilization (Table 3, Fig 3). It is show that the percentage of oil, protein content in seeds, increase in sowing date $(29 / 9 / 2017)$ and decreased at the delay. The decrease in the second date (29/10/2017) was due to high temperature $\left(19.1^{\circ} \mathrm{C}\right)$ between the flowering and the beginning of the formation of corns (Mar. month) (Table 1). This is confirmed by (Pritchard et al.1999) ${ }^{17}$ that the high temperature of more than $16{ }^{\circ} \mathrm{C}$ in the flowering stage leads to the decrease of oil in seeds between 12-15\% for each high in the temperature of the atmosphere one degree Celsius. Hauska et al. (2007) ${ }^{18}$ found the percentage of oil affected by climatic conditions.

In the present study, Field fertilizer application of (N 100 $\mathrm{kg} \cdot \mathrm{ha}^{-1}, \mathrm{P} 250 \mathrm{~kg} \mathrm{ha}^{-1}$ ) to winter rapeseed significantly affected the content of macronutrients and micronutrients in seeds and soil. In Al-Tuwaitha station showed increase significant differences in the $\mathrm{K}\left(64.9^{\mathrm{a}}-69.1^{\mathrm{b}} \mathrm{mg} \mathrm{kg}{ }^{-1}\right)$ and $\mathrm{Ca}\left(3.8^{\mathrm{a}}-5.8^{\mathrm{b}} \mathrm{mg}\right.$ $\mathrm{kg}^{-1}$ ) content of seeds, the content of other macronutrients ( $\mathrm{N}$, $\mathrm{Na}, \mathrm{P}, \mathrm{Fe}, \mathrm{Mg}, \mathrm{Cu}, \mathrm{Mn}$ and $\mathrm{S}$ ) in the seeds of winter rapeseed was not significantly influenced at fertilization, compared to no-fertilization (Table 4). In Al-Zafraniya station shows increasing significantly in the $\mathrm{Na}\left(2.7^{\mathrm{b}}-1.7^{\mathrm{c}} \mathrm{mg} \mathrm{kg}^{-1}\right), \mathrm{Ca}\left(7.3^{\mathrm{c}}-8.1^{\mathrm{d}}\right.$ $\left.\mathrm{mg} \mathrm{kg}{ }^{-1}\right), \operatorname{Mg}\left(3.2^{\mathrm{b}}-3.5^{\mathrm{c}} \mathrm{mg} \mathrm{kg}^{-1}\right)$, and decreased Fe $\left(94.1^{\mathrm{b}}-\right.$ $\left.85.2^{\mathrm{c}} \mathrm{mg} \mathrm{kg}^{-1}\right)$, content of seeds, The content of other macronutrients ( $N, K, P, C u, M n$ and $S$ ) in the seeds of winter rapeseed was not significantly influenced at fertilization, compared to no-fertilization (Table 4). The uptake and accumulation of micronutrients in different parts of crop plants (roots, shoots, seeds) are determined by the humus content of soil, the activity of microorganisms in the rhizosphere, soil pH, soil moisture content and fertilization. ${ }^{19}$

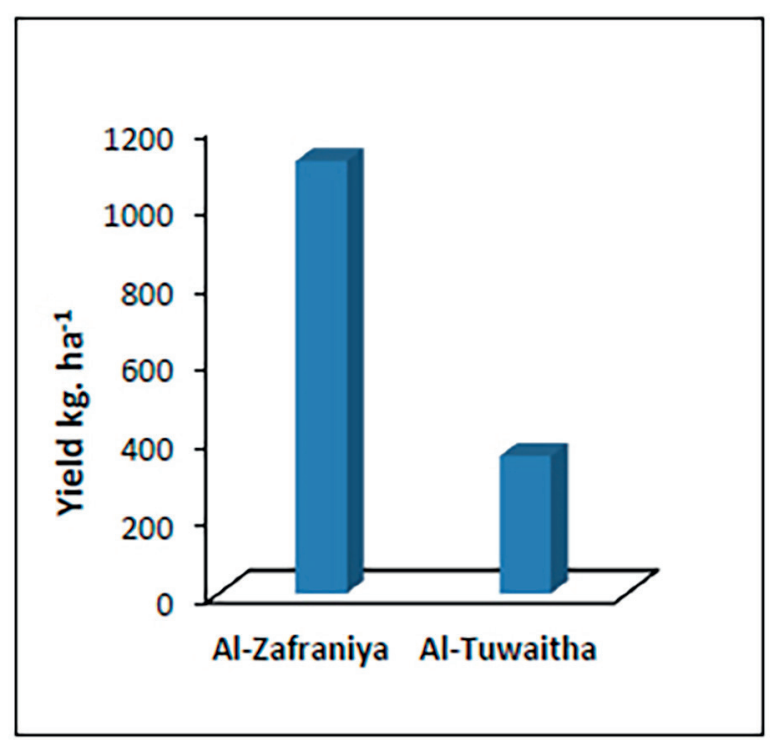

Fig 2. The yield $\left(\mathrm{kg} . \mathrm{ha}^{-1}\right)$ in locations

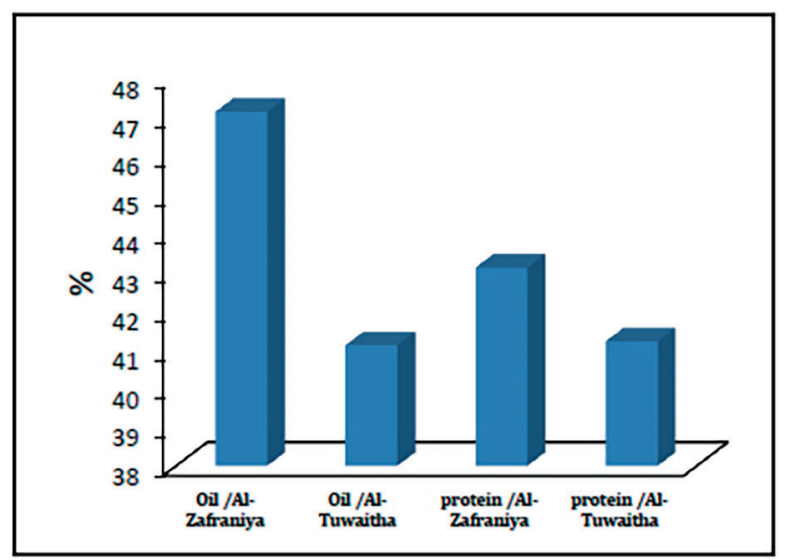

Fig 3. The percentage of oil and protein in locations

\begin{tabular}{|c|c|c|c|c|}
\hline \multirow[t]{2}{*}{ Parameter } & \multicolumn{2}{|c|}{ AL- Tuwaitha station (29/10/2017-29/6/2018) } & \multicolumn{2}{|c|}{ AL-Zafraniya station (29/9/2017-29/5/2018) } \\
\hline & No-Fer. $\left(\mathrm{kg} \cdot \mathrm{ha}^{-1}\right)$ & Fer. $\left(\mathrm{kg} \cdot \mathrm{ha}^{-1}\right)$ & No-Fer. (kg.ha $\left.{ }^{-1}\right)$ & Fer. $\left(\mathrm{kg} \cdot \mathrm{ha}^{-1}\right)$ \\
\hline Yield kg. ha-1 & $366.2^{\mathrm{a}}$ & $352.8^{\mathrm{a}}$ & $898.5^{b}$ & $1110.11^{c}$ \\
\hline HI \% & $22.04^{\mathrm{a}}$ & $24.5^{\mathrm{a}}$ & $27.07^{\mathrm{a}}$ & $28.21^{\mathrm{b}}$ \\
\hline Oil \% & $40.1^{\mathrm{a}}$ & $41.1^{\mathrm{a}}$ & $45.11^{\mathrm{a}}$ & $47.12^{\mathrm{a}}$ \\
\hline Seed protein \% & $40.3^{\mathrm{a}}$ & $41.2^{\mathrm{a}}$ & $42.1^{\mathrm{a}}$ & $43.1^{\mathrm{b}}$ \\
\hline Carbohydrate \% & $25.41^{\mathrm{a}}$ & $26.2^{\mathrm{b}}$ & $25.1^{\mathrm{a}}$ & $25.7^{\mathrm{a}}$ \\
\hline Ash \% & $3.94^{\mathrm{a}}$ & $4.36^{b}$ & $3.5^{\mathrm{a}}$ & $4.1^{\mathrm{b}}$ \\
\hline Fiber \% & $5.63^{\mathrm{a}}$ & $5.98^{b}$ & $5.63^{\mathrm{a}}$ & $6.27^{\mathrm{c}}$ \\
\hline Humidity \% & $6.3^{\mathrm{a}}$ & $6.52^{\mathrm{a}}$ & $7.05^{b}$ & $7.21^{b}$ \\
\hline
\end{tabular}

Table 3. Effect of field fertilizer on Yield seeds and Organic composition of seed of winter rapeseed in Al-Zafraniya station and AL- Tuwaitha station (2017-2018). Values marked with the same letter do not differ significantly at $p \leq 0.05$ 


\begin{tabular}{|c|c|c|c|c|}
\hline \multirow{2}{*}{$\begin{array}{c}\text { macro- } \\
\text { micro } \\
\text { nutrients } \\
\left(\mathrm{mg} \mathrm{kg}^{-1}\right)\end{array}$} & \multicolumn{2}{|c|}{ Al-Tuwaitha station } & \multicolumn{2}{|c|}{ Al-Zafraniya station } \\
\hline & No-Fer(kg.ha-1) & Fer. $\left(\mathrm{kg} \cdot \mathrm{ha}^{-1}\right)$ & No-Fer. $\left(\mathrm{kg} \cdot \mathrm{ha}^{-1}\right)$ & Fer. $\left(\mathrm{kg} \cdot \mathrm{ha}^{-1}\right)$ \\
\hline $\mathbf{N}$ & $22.1^{\mathrm{a}}$ & $25.1^{\mathrm{a}}$ & $33.4^{\mathrm{b}}$ & $33.9^{6}$ \\
\hline $\mathbf{K}$ & $64.9^{\mathrm{a}}$ & $69.1^{\mathrm{b}}$ & $84.5^{\mathrm{c}}$ & $80.2^{\mathrm{c}}$ \\
\hline Na & $1.2^{\mathrm{a}}$ & $1.4^{\mathrm{a}}$ & $2.7^{b}$ & $1.7^{\mathrm{c}}$ \\
\hline Ca & $3.8^{\mathrm{a}}$ & $5.8^{\mathrm{b}}$ & $7.3^{\mathrm{c}}$ & $8.1^{\mathrm{d}}$ \\
\hline Mg & $2.1^{\mathrm{a}}$ & $2.5^{\mathrm{a}}$ & $3.2^{b}$ & $3.5^{c}$ \\
\hline $\mathbf{P}$ & $4.3^{\mathrm{a}}$ & $4.6^{a}$ & $5.8^{b}$ & $6.3^{b}$ \\
\hline $\mathrm{S}$ & 1.8 & 1.8 & 2.9 & 3 \\
\hline $\mathrm{Fe}$ & $64.9^{a}$ & $66.8^{a}$ & $94.1^{b}$ & $85.2^{c}$ \\
\hline Mn & 34.6 & 35.7 & 59.2 & 58.1 \\
\hline $\mathrm{Cu}$ & 3 & 2.8 & 3 & 2.3 \\
\hline
\end{tabular}

Table 4. Effect of field fertilizer on the nutrient content of seed of winter rapeseed in Al-Zafraniya station and Al-Tuwaitha station (2017-2018).

Macro-micro nutrients. Values marked with the same letter do not differ significantly at $\mathrm{p} \leq 0.05$

Data presented in Table (5) showed, in Al-Tuwaitha station found increasing significantly in the $\mathrm{Mg}\left(219.2-222.2 \mathrm{mg} \mathrm{kg}^{-1}\right)$, $\mathrm{Fe}\left(3.8\right.$ - $\left.5.8 \mathrm{mg} \mathrm{kg}^{-1}\right)$ and decreased $\mathrm{Na}\left(1257.3-1190 \mathrm{mg} \mathrm{kg}^{-1}\right)$ content of soil. The content of other macronutrients ( $N, \mathrm{~K}, \mathrm{Ca}$, $\mathrm{P}, \mathrm{Cu}, \mathrm{Mn}$ and $\mathrm{S}$ ) was not significantly influenced at fertilization, compared to no-fertilization. In Al-Zafraniya station shows increasing significantly in the EC $\left(5.7^{\mathrm{a}}-6.01^{\mathrm{b}}\right), \mathrm{K}\left(128^{\mathrm{b}}-135^{\mathrm{g}}\right.$ $\left.\mathrm{mg} \mathrm{kg}^{-1}\right)$, Na $\left(1300.7^{\mathrm{c}}-1317.3^{\mathrm{c}} \mathrm{mg} \mathrm{kg}^{-1}\right)$, Ca $\left(1257^{\mathrm{b}}-1397^{\mathrm{c}}\right.$ $\left.\mathrm{mg} \mathrm{kg}{ }^{-1}\right), \mathrm{Mg}\left(320^{\mathrm{c}}-399^{\mathrm{d}} \mathrm{mg} \mathrm{kg}^{-1}\right), \mathrm{S}\left(2.9^{\mathrm{a}}-3^{\mathrm{b}} \mathrm{mg} \mathrm{kg}^{-1}\right)$, Fe $\left(0.97^{\mathrm{c}}-1.2^{\mathrm{d}} \mathrm{mg} \mathrm{kg}^{-1}\right), \mathrm{Cu}\left(0.88^{\mathrm{b}}-1.17^{\mathrm{c}} \mathrm{mg} \mathrm{kg}^{-1}\right)$ content of soil and decreased $\mathrm{pH}\left(6.55^{\mathrm{b}}-6.11^{\mathrm{c}}\right)$, at fertilization, compared to no-fertilization. The results show that the soil in Al-Zafraniya station contains nutrients higher than the Al-Tuwaitha station: this may be due the fertility of Al-Zafraniya soil compared to Al-Tuwaitha soil. As well as soil texture (silt clay loam), decrease the $\mathrm{pH}\left(6.55^{\mathrm{b}}-6.11^{\mathrm{c}}\right)$ when addition of fertilizers and different weather condition of temperature, rainfall, and humidity (Table 1). Management of plant nutrition is important to prevent acidic reactions in reducing nutrient availability in the soil. Soil pH regulates the capacity of soils to store and supply nutrients, and thus contributes substantially to controlling productivity in terrestrial ecosystems (Brady, N. C. \& Weil, R. R., 2002 ${ }^{20}$.

Values marked with the same letter do not differ significantly at $p \leq 0.05$

\section{Conclusions}

The results showed increases with Yield (1110.11 kg. ha-1), percentage of oil (47.12\%), protein content in seeds (43.1\%), carbohydrate (25.7\%) in Al-Zafraniya location compared with Al-Tuwaitha location which gave decrease in Yield (352.8 $\mathrm{kg}$. ha-1), percentage of oil (41.1\%), protein content in seeds (41.2\%), carbohydrate (26.2\%). Agriculture in 29- September was better than agriculture in 29-October for a high yield of seeds, protein and oil. The high temperature from $18-26^{\circ} \mathrm{C}$ during the flowering period of rapeseeds leads to decrease in the seed yield and percentage of oil, protein in seeds.

\section{References}

1. Abdulkhaleq, D.A., Hama, S.J., Ahmad, R.M. and Ismael, S., 2018. Response of some Rapeseed (Brassica napus L.) varieties to $\mathrm{Zn}$ fertilizer Under Dry farming Conditions

2. Al-Doori, S.A.M. and M.Y., Hasan 2010. Effect of row spacing and nitrogen fertilization on growth, yield and quality of some rapeseed genotypes. J. Res. 9 (4): 531-550.

3. Al-Mandil F. A. and Kanah A. M., 2017. Effect of soils on the composition of active compounds in the type Brassica napus L. growing in Iraq. Tikrit Journal of Pure Science, 22 (10).

4. Anne, M., B., and R. Michel (1999). Effect of temperature and water stress on fatty acid composition of Rapeseed oil. In "New horizon for an old crop", proc .10 International Rapeseed Congress. Canberra - Australia. 26 - 29 Sept.

\begin{tabular}{|c|c|c|c|c|}
\hline \multirow{2}{*}{$\begin{array}{c}\text { macro- } \\
\text { micro } \\
\text { nutrients } \\
\left(\mathrm{mg} \mathrm{kg}^{-1}\right)\end{array}$} & \multicolumn{2}{|c|}{ Al-Tuwaitha station } & \multicolumn{2}{|c|}{ Al-Zafraniya station } \\
\hline & No-Fer(kg.hat $\left.{ }^{-1}\right)$ & Fer. $\left(\mathrm{kg} \cdot \mathrm{ha}^{-1}\right)$ & No-Fer. $\left(\mathrm{kg} \cdot \mathrm{ha}^{-1}\right)$ & Fer. $\left(\mathrm{kg} \cdot \mathrm{ha}^{-1}\right)$ \\
\hline $\mathbf{N}$ & $22.1^{\mathrm{a}}$ & $25.1^{\mathrm{a}}$ & $33.4^{b}$ & $33.9^{6}$ \\
\hline $\mathbf{K}$ & $64.9^{a}$ & $69.1^{b}$ & $84.5^{c}$ & $80.2^{c}$ \\
\hline Na & $1.2^{\mathrm{a}}$ & $1.4^{\mathrm{a}}$ & $2.7^{\mathrm{b}}$ & $1.7^{\mathrm{c}}$ \\
\hline $\mathrm{Ca}$ & $3.8^{\mathrm{a}}$ & $5.8^{b}$ & $7.3^{c}$ & $8.1^{d}$ \\
\hline Mg & $2.1^{\mathrm{a}}$ & $2.5^{\mathrm{a}}$ & $3.2^{6}$ & $3.5^{\mathrm{c}}$ \\
\hline $\mathbf{P}$ & $4.3^{a}$ & $4.6^{a}$ & $5.8^{6}$ & $6.3^{b}$ \\
\hline $\mathrm{S}$ & 1.8 & 1.8 & 2.9 & 3 \\
\hline Fe & $64.9^{a}$ & $66.8^{a}$ & $94.1^{b}$ & $85.2^{c}$ \\
\hline Mn & 34.6 & 35.7 & 59.2 & 58.1 \\
\hline $\mathrm{Cu}$ & 3 & 2.8 & 3 & 2.3 \\
\hline
\end{tabular}

Table 5. Effect field fertilizer on the nutrient content of soil of winter rapeseed in Al-Zafraniya station and Al-Tuwaitha station (2017-2018) 
5. AOAC. Official method of Analysis of the Association of official Analytical chemists. 15th Ed. Washington. DC, 2004.

6. Brady, N. C. \& Weil, R. R., 2002. The Nature and Properties of Soils 15th edn, 375-419

7. Cohen, J.H.; Kristal A.R. and Stanford, J.L., 2000. Fruit and vegetable intakes and prostate cancer risk. J. Natl. Cancer Inst. 92: 61-68.

8.Grzebisz, W. 2008. Nawożenieroślinuprawnych. Part 1. Podstawynawożenia. Poznań, Poland: PaństwoweWydawnictwoRolniczeiLeśne. 428 p. (in Polish).

9. Hänsch, R. \& Mendel, R.R. 2009. Physiological functions of mineral micronutrients ( $\mathrm{Cu}, \mathrm{Zn}, \mathrm{Mn}, \mathrm{Fe}, \mathrm{Ni}, \mathrm{Mo}, \mathrm{B}$, and $\mathrm{Cl}$ ). Current Opinion in Plant Biology 12: 259266

10. Hassan, K. H. and M. S. El-Hakeem. 1996. Response of some rapeseed cultivars to nitrogen rates and plant density under saline conditions. Annual Agriculture Science, Ain-Shams Univ. Egypt. 41(1): 229-242.

11. Hauska, D., C. Oertel, L. Alpmann, D. Stelling and H. Bush (2007): Breeding progress towards high oil content in oil seed rape (Brassica napus $L$.) essential innovations to meet current and future market needs, proc. 12th International Rapeseed Congress Wuhan China, 1, $159-162$.

12. Hocking, P. J. 1997. Assessment of the nitrogen status of field grown Rapeseed (Brassica napus L.) by plant analysis. Australian Journal of Experimental Agriculture. 37 (1): 83-92.

13. Jankowski, K., Kijewski, Ł., Skwierawska, M., Krzebietke, S. \&Mackiewicz-Walec, E. 2014. The effect of sulfur fertilization on the concentrations of copper, zinc and manganese in the roots, straw and cake of rapeseed (Brassica napus L. ssp. oleifera Metzg). Journal of Elementology 19: 433446.

14. Mendham, N.J., P.A. Ship Way and P.K. Scott (1981). The effect of delayed sowing and weather on growth, development and yield of winter oilseed rape (Brassica napus L.), J. Agric. Sci., Camb. 96: $384-416$.
15. Pritchard, F.M., R.M. Norton, H.A. Eagles, P.A. Salisbury and M. Nicdas (1999). The effect of environment on Victorian Canola quality. In "New horizons for an old crop ", proc. Of the 10th Inter. Rapeseed Congress. Canberra - Australia, 26 - 29 Sept.

16. Page AL, Miller RH, Kenney DR. Method of Soil Analysis, 2nd (ed) Agron. 9, Publisher, Madiason, Wisconsin, 1982.

17. Rahman, R.M., M.A. Malik, Z. Ali, M.A. Cheema and N. Aktar (2000). Determining a suitable seeding time and seed rate for harvesting arich crop of canola (Brassica napus L.), Pakistan J. of Biological Sci. 3(3): $534-536$

18. Robertson, M.J., J.F. Holland, R. Bambach, S. Cawthray (1999). Response of canola and Indian mustard to sowing date in risky Australian environments. Proceeding of the 10th International Rapeseed Congress, Canberra - Australia, 26 - 29 Sept.

19. Sharief, A. E. 2000. Response of some Rapeseed Cultivars, (Brassica napus L.) to different Sources and levels of nitrogen fertilizer in Soil effected By Salinity Zigzag Journal Agriculture Res. Egypt. 27 (3): 603-616.

20.Shirani, A. H. and M. R. Ahmedi. 1995. Effect of fertilizers and plant density on agronomical characters of two rapeseed cultivars. Seed and plant Journal Agriculture Res., Seed and plant Improvement Institute. Iran Islamic Republic. 11(2):22-28.

21. SAS Institute Inc. SAS/STAT User's guide. Version 8.SAS Institute, Cary, North Carolina, USA, 1999.

22. Taifour and others, 1990. Oil crops, University of Mosul, Ministry of Higher Education and Scientific Research, 316 pages.

Received: 5 September 2018

Approved: 10 January 2019 